\title{
The Influence Of Double Branding Strategy On Consumer Appeal Of Bulog Public Corporation Regional Division Of Sulselbar In Makassar City
}

\author{
Winalda Adelia ${ }^{1}$, Haedar Akib ${ }^{2}$, Muh.Rizal ${ }^{3}$, Andi Aslinda ${ }^{4}$ \\ Program Studi Ilmu Administrasi Bisnis, Universitas Negeri Makassar \\ Email: winaldaadelia@gmail.com
}

\begin{abstract}
The aims of this research are (1) To know the overview of the double branding strategy of Bulog public corporation regional division of Sulselbar in Makassar city. (2) To know the influence factors of consumer attractiveness to KITA's products at Bulog of Sulselbar in Makassar city. (3) To know the influence of the double branding strategy model to consumer attractiveness at Bulog of Sulselbar in Makassar city. The type of this research is a simple regression analysis with a quantitative approach. To achieve the above aims using data collection techniques through observation, questionnaires, and documentation and analyzed using statistical formulas. The results showed that the double branding strategy had an effect on consumer attractiveness. with a correlation coefficient value of 0.775 and a coefficient of determination of 60.1 percent.
\end{abstract}

Key words: Double Branding (X) and Attractiveness (Y)

\section{INTRODUCTION}

The real market is the association of consumers who have interest, income, and access to a particular product or service. In the real market, consumers usually make transactions. If in the real market the buyer has the interest or desire to buy with the support of access and income, then in the buyer market the buyer only has the interest but is not supported by the ability or access to buy. In general, the factors that influence the demand for a good or service according to (Sadono Sukirno, 2004) is "the price of the good itself, the price of other related goods (substitute or complementary goods), income, taste, population, and special factors (access)." the purpose of marketing is how the goods and services produced are liked, in demand, needed and purchased by consumers for a long period of time. Talking about marketing objectives, we must know at least seven things, especially in the field of production of an item, namely product, price, place, promotion, people, process, and physical evidence (Dharma \& Akib, (Adunola Oke,Parinda Kamolshotiros, Oluwamayowa Yewande Popoola, 2016). According to (Delianti, 2012) "Marketing is the process of planning and implementing the conception, pricing, promotion and distribution of ideas, goods and services to create exchanges in order to satisfy both the customer and the company." While (Keller, 2008) defines marketing "as a social and managerial process in which individuals and groups get what they need and want by creating and exchanging products and values with other parties." 
Every company always tries to stay alive, thrive, and be able to compete. In this context, every company always determines and implements strategies and methods of implementing its marketing activities. According to (Winarto, S., Niswaty, R., 2015) "Strategy is a framework or plan that integrates the goals (goals), policies (policies), and actions / programs (programs) of the organization." In this marketing strategy, there is a marketing mix strategy, which determines the best composition of the four components or marketing variables, in order to achieve the target market as well as achieve the goals and objectives of the company. The four components, namely product, plot, price, and promotion, are then developed or added to the 7P. The additions are packaging, positioning, and people (Aras, M., Syam, H., Haris, H., Jasruddin, M., \& Akib, 2020). Marketing strategy helps improve employee competence (Henni Zainal, Parinsi, Indonesia, Hasan, \& Makassar, 2018; Effendy, 2018).

In an era of increasingly sharp business competition, branding efforts are increasingly becoming a complex and fluctuating matter. A product can be distinguished from other products in terms of brand. Brand or brand as described by the American Marketing Association (AMA) is a name, terminology, sign, symbol, design, or a combination of the four, which is intended to identify goods or services from a sales group that is different from its competitors. (Lukman, 2000). According to (Aaker, 2015) revealed that: "The strength of a brand / brand in a product with a double branding strategy can affect the attractiveness of potential consumers to buy a good or service, depending on the good and bad image that is attached to the brand." Before the brand is published to the public, the company must first compile the brand, such as a logo, tagline, message in the brand itself, and others. To convey the brand to the public, companies usually make a branding strategy. There are four elements of brand equity according to (Sulandari, 2018), namely "brand awareness, brand association, perceived quality, and brand loyalty." These four things are stages that the company will definitely go through. So before companies achieve brand loyalty, they will definitely go through brand awareness first. From the brand equity element, it can be seen how big a company is. If the company is still only doing brand awareness, then it can be ascertained that the company is a new company that has just formed a brand and published it so that the public knows the brand. It is different for large companies, usually large companies have reached the brand loyalty stage where the company can measure the loyalty of its customers and see their loyalty to any product produced by the company.

One of the companies in Indonesia that started developing its product brand and retail network in 2017 and was rewarded with three awards as well as the best brand strategy, the best corporate communication and the most popular soe in wholesale and retail trade in the BUMN branding \& marketing award 2018 which was held by Markplus, namely Perum BULOG. Starting from the strengthening of the branding of BULOG as a corporation and branding of KITA as superior food products that will compete in the market, it is necessary to make innovation efforts from every BULOG employee. With its superior products under the "KITA brand flag" which focus on rice, cooking oil, meat, sugar, and wheat products, this is one of the strong indicators for Perum BULOG to change and get out of its comfort zone so far. What should be done by Perum BULOG is an effort to socialize Perum BULOG with this KITA brand strategy. Based on the following description, in this study the author raises the title "The Effect of Double Branding Strategy on Consumer Attractiveness at Perum BULOG Divre South and West Sulawesi in Makassar City".

\section{METHOD}

This type of research is a type of simple linear regression analysis. This study uses a quantitative research approach (Sugiyono, 2017) argues that: "A quantitative research approach can be interpreted as a research approach based on the philosophy of positivism, used to research on certain populations or samples, data collection using research instruments, quantitative / statistical data analysis, with the aim of testing the hypothesis that has been applied. " The research design or steps used in this research are the first, namely a preliminary study conducted by reviewing the 
location or it can be called a pre-research, namely Perum BULOG Divre Sulselbar in Makassar City. In this study the population is all consumers / communities on Jl. Tamangapa raya 3 Antang, Bangkala, Manggala District, Makassar City, as many as 150 respondents. "The sample is part of the number and characteristics of the population. The sampling technique is called the sampling technique (Sugiono, 2017). The sampling technique in this research was carried out using simple random sampling technique, which is a random sampling technique without paying attention to the existing strata. Data collection techniques used (1), observation techniques; (2) questionnaire; (documentation). The data analysis technique used is the validity and reliability test of the data. The validity test is useful to find out whether there are questions on the questionnaire that must be discarded / replaced because they are considered irrelevant. Inferential analysis is used in parametric and nonparametric statistics.

\section{RESULTS AND DISCUSSION}

The questionnaire data processing shows that the majority of respondents are over 33 years old, this means that most consumers / customers who buy KITA Perum BULOG products are elderly people and the majority of respondents work as housewives who prioritize their family's basic needs. Meanwhile, figure 6 shows that the majority of respondents made purchases based on the length of time they were customers, namely during the period of 1 year.

The results showed that double branding can have an influence on consumer attractiveness. SPSS output data with a regression test between double branding and attractiveness obtained a constant value (a) of 17,011, stating that if the double branding variable is all considered zero or no value, then the attractiveness value is 17,011 . The regression coefficient $X$ (double branding) of 0.818 states that for every 1 percent increase in the value of double branding, assuming other variables do not change or in a constant condition, the participation value increases by 0.818 . The regression coefficient is positive, so it can be said that the direction of the influence of the variable $\mathrm{X}$ on $\mathrm{Y}$ is positive. So the regression equation is $\mathrm{Y}=17.011+0.818 \mathrm{X}$. Based on the results of the f-test that has been carried out, it can be seen that the significance value is less than 0.05 , namely $0.000<0.05$ and the calculated $\mathrm{f}$ value> $\mathrm{f}$ table is $162,759>3.93$. So it can be concluded that the double branding strategy simultaneously has a positive and significant effect on consumer attractiveness at Perum BULOG Divre Sulselbar in Makassar City. This shows that the double branding strategy through price, packaging, quality, and promotion indicators has been made well by branding. This is in accordance with Aaker's opinion which states that even though it is difficult, branding is very feasible and important. A key to building a brand to success is understanding how to build a brand identity, which means that we really understand what the brand is presented for, and how to effectively express the identity of the brand to users.

Through the attractiveness indicators used in this study are the suitability of quality, product features, style and design, and brand, namely the stage where consumers are interested and make purchases and measure satisfaction with the brand. This is in accordance with the opinion of Kotler and Keller which distinguishes product attractiveness based on several things that can affect consumer desires such as shape, features, adjustments, performance quality, quality suitability, durability, reliability, ease of repair, brand style and design. To form attractiveness to products, companies need to create high-quality products to provide more value than competing products to create consumer appeal to the product. From the overall statements on each of these indicators, it can be concluded that the best way to build a brand identity using a double branding strategy is product quality and an effective way of expressing the identity of the brand to users is through promotions carried out through online and offline channels.

Respondent response data regarding competence, so for the first indicator that always presents himself as a person who is stable, stable, mature, wise, and authoritative, the average respondent gives quite agreeable answers, namely 39 people (62.9\%), the second indicator develops themselves continuously as professional educators, most respondents gave agreed answers, namely as many as 36 
106| Jurnal Office: Jurnal Pemikiran Ilmiah dan Pendidikan Administrasi Perkantoran

Vol. 6, No. 2, July-December 2020, Page 103-110

people $(58.1 \%)$, the third indicator was able to assess their own performance related to the achievement of educational goals, dominated by the majority of respondents' answers were quite agreeable, namely 28 people $45.2 \%$ ). Then the fourth indicator regarding the ability to complete work professionally, the most respondents' answers are agreeing with the number of respondents as many as 32 people $(51.6 \%)$, while the fifth indicator is that attitudes reflect behavior that supports work activities, on average respondents give answers agree with The number of respondents was 29 people (46.8\%), thus it can be concluded that the average employee who works at the Educational Foundation in Makassar already has competence. Table 2 shows the responses of respondents regarding discipline, so for the first indicator that every employee understands the strict rules and regulations, the average respondent gives a fairly agreeable answer, namely 33 people (53.2\%), the second indicator is about always being present on time To the office, it appears that most of the respondents gave agreed answers, namely as many as 53 people $(56.5 \%)$. Then the third indicator is that following all the regulations of the Education Foundation, dominated by the majority of respondents' answers are agreeing, namely as many as 31 people $(50 \%)$, the fourth indicator is responsible for every given task, on average the respondents gave agreed answers, namely 31 people $(50 \%)$, while the fifth indicator follows the leader's instructions to work carefully, the most respondents' answers were quite agree with the number of respondents 24 people (38.7). Respondents' responses regarding Mochammad Natzir Education Foundation giving awards for outstanding employees, the average respondent gave fairly agreeable answers, namely 33 people (53.2\%), the second indicator is that Mochammad Natzir Education Foundation provides compensation through the provision of salaries, allowances and incentives, Most of the respondents gave quite agreeable answers, namely 28 people $(45.2 \%)$ respectively. The second indicator is the need for achievement and good work results from each employee, most of the respondents gave fairly agreeable answers, namely 31 people (50\%). The fourth indicator for the policy of giving incentives is satisfactory, most of the respondents gave agreed answers, namely as many as 26 people (41.9\%), while the fifth indicator was that they had the opportunity to carry out a promotion, the most respondents answered agreed, namely 27 people (43.5\%).

Respondents' responses regarding job satisfaction, then for the first indicator that I receive a salary in accordance with workload and responsibility, the average respondent answers quite agree, namely 34 people $(54.8 \%)$, the second indicator is that I work in a safe work environment, clean and comfortable, most of the respondents gave agreed answers, namely as many as 28 people $(45.2 \%)$, the three indicators of the work environment encouraged my enthusiasm in completing work, most respondents answered quite agree, namely 30 people (48.4\%), indicators The four leaders always provide direction to employees in every job, dominated by the most respondents' answers are quite agreeable, namely 24 people (38.7\%), while the fifth indicator is that employee and leadership communication is well established in solving work problems, the average respondent gives Enough answers agree, namely as many as 30 people $(48.4 \%)$.

The results of this study indicate that the results of the regression coefficient analysis for competence are 0.325 , and have a p-value of 0.0029 , so it can be concluded that competence has a positive and significant effect on employee performance at the Mochammad Natzir Education Foundation in Makassar. From the results of the regression coefficient for discipline of 0.290, and has a p-value of 0.033 , it can be concluded that discipline has a positive and significant effect on employee performance at the Mochammad Natzir Education Foundation in Makassar. Based on the results of the regression coefficient analysis for motivation of 0.195 , and has a p-value of 0.008 , it can be concluded that motivation has a positive and significant effect on employee performance at the Mochammad Natxir Education Foundation in Makassar. From the analysis of the regression coefficient for job satisfaction of 0.185 , and has a p-value of 0.004 , it can be concluded that competence has a positive and significant effect on employee performance at the Natzir Education Foundation in Makassar. 
The problem of competence is one of the factors that affect employee performance, while the results of research conducted by researchers, especially at the Office of the Educational Foundation in Makassar. Findings were obtained that employees who work at the Mochmmad Natzir Education Foundation office always present themselves as stable, stable, mature, wise, and authoritative individuals, then in increasing the competence of their employees, each employee has developed themselves continuously as professional educators. . Then efforts to improve competence for each employee, every employee who works at the Mochammad Natzir Education Foundation Office has the ability to assess their own performance in achieving educational goals which have been the vision and mission in educational development. So far, every employee has been able to complete the work at the Educational Foundation office in Makassar. Then from the results of the partial testing that has been done, it shows that competence has a significant effect on employee performance. It can be said that the increase (decrease) in competence possessed by each employee will significantly improve employee performance, especially at the Mochammad Natzir Education Foundation Office in Makassar. Hendri (2005), examined the effect of competence on employee performance. The results of statistical data analysis show that the influence of competency variables on employee performance has a significant and positive effect on employee performance.

Discipline issues are one of the aspects that affect employee performance, especially at the Mochammad Natzir Education Foundation Office in Makassar. The findings show that in order to improve employee discipline, every employee who works at the Mochammad Natzir Education Foundation office in Makassar already understands the strict rules and regulations. In addition, every employee is always present on time to the office, so it can be said that employees work on time. And besides that every employee has followed all the regulations of the Mochammad Natzir Education Foundation. Then the employee is responsible for each assigned task and besides that, he has followed the leadership's instructions to work carefully. Based on the results of research conducted, it shows that discipline has a positive effect on employee performance. This shows that the high discipline of employees in completing work will be able to affect the performance improvement of employees who work at the Education Foundation in Makassar, while the partial test results show that work discipline has a significant effect on employee performance. Other findings suggest that employee discipline can improve employee performance (Rakib, Zainal, Farwita, \& Yusriadi, 2019; Zainal, 2017; Zainal, Baharuddin, \& Farwita, 2019).

Employee work motivation has an effect on employee performance, it is found that every employee. Those who excel receive awards from the Education Foundation and in addition to be able to improve the performance of the foundation's pioneering employees, provide compensation through the provision of salaries, allowances and incentives that support the life needs of employees. Then in improving employee performance. So every employee who works at the Mochammad Natzir Education Foundation Office in Makassar needs good performance and work results and besides that the policy of providing incentives has provided satisfaction for every employee who works at the Education Foundation Office.

Educational foundations always provide opportunities for promotion .(Yoga Arsyenda, 2013), who obtained findings that work motivation has a positive and significant effect on employee performance. Job satisfaction is a factor that can improve employee performance, especially at the Mochammad Natzir Education Foundation in Makassar. It is found from the results of distributing questionnaires to each employee who is the respondent, it turns out that each employee has increased employee satisfaction working at the Mochammad Natzir Education Foundation in Makassar, where the respondent's perception that the salary given is in accordance with workload and responsibility and besides that employees who work in a safe, clean and comfortable work environment. Furthermore, his work environment, especially at Mochammad Natzir Education has encouraged employee morale in completing work. And besides that the leadership always provides direction to employees in completing work that is well established in completing every job and besides that there is employee communication and is always well established in completing every job. So from the results of this study it can be said that the level of job satisfaction, especially at the Mochammad 
108| Jurnal Office: Jurnal Pemikiran Ilmiah dan Pendidikan Administrasi Perkantoran

Vol. 6, No. 2, July-December 2020, Page 103-110

Natzir Education Foundation in Makassar, is good enough so that it can improve employee performance.(Sedhana Yasa Putu I\&Muiartha Utama Wayan I, 2013), examine the effect of job satisfaction on employee performance. The results showed that job satisfaction has a significant effect on employee performance.

\section{CONCLUSION}

Based on the results of the analysis and research, several conclusions will be presented, namely: Double Branding is building two brands in one unit. Branding BULOG as Corporate and Branding KITA brand as BULOG brand, are one unit. Cannot walk alone. The essence of talking about KITA Rice, KITA Flour, KITA Sweet Sugar, KITA Cooking Oil, KITA to KITA Meat is talking about BULOG. In terms of double branding, we can see that the brand name being sold is BULOG as an organization and KITA's brand as a product. The KITA brand as a product for Indonesian families must show a positioning that offers a different value proposition from its competitors. Both of these challenges have been proven by Perm BULOG, sales of commercial rice and premium products with the KITA brand have a much higher sales potential than the previous year, it can be seen from the growth in commodity sales from 2016-2018, experiencing an increase in sales every year. This is supported by the various advantages of commercial rice and premium products with the KITA brand that are marketed. The advantages of KITA's products are also found in the quality packaging of our KITA products, the prices of our products are cheap and affordable, the prices of our products can compete with similar products, and the prices of our products are in accordance with the expected value. It has been proven that with the double branding strategy model, companies are given access to more customers and can offer a variety of superior products and services. Each product must have its own advantages that it displays. Like the KITA product brand owned by Perm BULOG, it has various advantages that can attract people purchasing power. For a consumer, goods are not only physical objects but also include other attributes (factors) related to the goods / products so that they have a special attraction. Factors that influence consumer attractiveness to KITA products such as the suitability of quality, features, brand, style and design. These factors support the selling value of our products in the eyes of consumers. This can also be seen in the commercial products of Perm BULOG which always attract the public because they always provide quality food supported by strong packaging and branding. Based on the results of simple linear regression analysis, the double branding strategy (X) has a positive effect on consumer attractiveness $(\mathrm{Y})$. The contribution or influence of the double branding strategy on consumer attractiveness is at strong intervals of its influence on consumer attractiveness at Perm BULOG Divre Sulselbar in Makassar City.

\section{REFERENSI}

Aaker, D. (2015). Aaker On Branding(20 prinsip esesnsial mengelola dan mengembangkan brand). Bandung: Gramedia Pustaka Utama.

Adunola Oke,Parinda Kamolshotiros, Oluwamayowa Yewande Popoola, M. A. A. (2016). Consumer Behavior towards Decision Making and Loyalty to Particular Brands. International Review of Management and Marketing, 6(4), 43-52.

Aras, M., Syam, H., Haris, H., Jasruddin, M., \& Akib, H. (2020). The Analysis of Mix Marketing System Toward The Perfomance of Convection Business in Makassar. ICSS, 1104-1107. Retrieved from https://doi.org/10.2991/icss-18.2018.233 
Delianti, O. (2012). Manajemen Pemasaran Modern. Yogyakarta: LaksBang PRESSindo.

Effendy, A. A. (2018). Analysis of Marketing Strategies to Increase Sales at PT. Karya Tunggal Properti. Jurnal Office: Jurnal Pemikiran Ilmiah dan Pendidikan Administrasi Perkantoran, 4(2), 103-108.

Zainal, Henni, etc all.(2018). The Influence Of Strategic Assets And Market Orientation To The Performance Of Family Business In Makassar City, Indonesia. Academy of Strategic Management Journal.17(6), 1-9.

Keller, P. K. and K. L. (2008). Manajemen Pemasaran. ke-13. Jakarta: Erlangga.

Lukman, S. (2000). Manajemen Kualitas Pelayanan. Jakarta: STIA - LAN Press.

Rakib, M., Zainal, H., Farwita, S., \& Yusriadi, Y. (2019). The Improvement of Employees ' Performance in South Sulawesi, Indonesia. International Journal of Recent Technology and Engineering. 8(4), 1007-1010.

Sadono Sukirno, E. a. (2004). Pengantar Bisnis. Jakarta: Kencana Prenada Media Grup.

Yasa, I Putu Sedhana \& Utama, I Wayan Mudiartha (2014). Pengaruh Kompensasi dan Lingkungan Kerja terhadap Kepuasan Kerja dan Kinerja Karyawan pada Karma Jimbaran. E- Jurnal Manajemen. 3(13).

Sudaryono. (2015). Pengantar Bisnis Teori \& Contoh Kasus. Yogyakarta: CV Andi Offset.

Sugiyono. (2017). Metode Penelitian kuantitatif, kualitatif, dan $R \& D$ Cetakan ke- 19. Bandung: Alfabeta.

Sulandari, E. (2018). BULOG Penyebar Informasi. Edisi ke-3. Jakarta: Warta Intra BULOG.

Winarto, S., Niswaty, R., \& . J. (2015). Strategi Pengembangan Daya Tarik Wisata Balla Lompoa Di Kabupaten Gowa Provinsi Sulawasi Selatan. Jurnal Ad'ministrare, 2(2).

Yoga Arsyenda. (2013). Pengaruh Motivasi Kerja dan Disiplin terhadap Kinerja PNS (studi kasu pada Bappeda Kota Malang). Malang.

Zainal, H. (2017). Influence of Work Motivation and Discipline on Work Productivity . 2nd International Conference on Education, Science, and Technology (ICEST 2017) (pp. 25-27). Amsterdam, The Netherlands: Atlantis Press.

Zainal, H., Baharuddin, A., \& Farwita, S. (2019). Disiplin Kerja Karyawan Pada PT . Taspen ( Persero ) KCU Makassar. Pinisi Business Administration Review. 1(2), 101-106. 
110| Jurnal Office: Jurnal Pemikiran Ilmiah dan Pendidikan Administrasi Perkantoran Vol. 6, No. 2, July-December 2020, Page 103-110 